Duduleanu, L. (2021). Arthropods. Aesthetic approaches through selective methods of representation in personal creation. Scientific view on the modern problems of cultural heritage and arts in the context of social development. Klironomy, 1 (1), 43-53. Hlučín-Bobrovníky: “Anisiia Tomanek” OSVČ.

Duduleanu, L. (2021). Artopode. Aprofundări estetice ale tematicii prin metode selective de reprezentare în creația personală. Scientific view on the modern problems of cultural heritage and arts in the context of social development. Klironomy, 1 (1), 43-53. Hlučín-Bobrovníky: “Anisiia Tomanek” OSVČ.

DOI: $10.47451 /$ her2021-04-002

EOI: $10.11249 /$ her2020-04-002

The paper is published in Crossref, Internet Archive, Google Scholar, Academic Resource Index ResearchBib, JGate, ISI, CiteFactor, ICI, eLibrary databases.

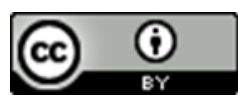

Laura Duduleanu Assistant, Doctor of Visual Arts Department of Graphics Faculty of Arts and Design West University of Timisoara Timisoara, Romania E-mail: dorina.duduleanu@e-uvt.ro

\title{
Arthropods. Aesthetic approaches through selective methods of representation in personal creation
}

Abstract:

The article purpose is to analyze the theme of insects in the sphere of visual arts from the perspective of the visual artist, as basis of the research, presenting certain historical, technical, artistic and conceptual aspects. The present study highlights the representations of certain specimens in the area of artistic creation and analyzes three stages of the creative act - from simple curiosity to science and to purely aesthetic value - the observations made in the field of entomology being part this. Surprising the phenomenon of decontextualization of arthropods in the natural environment leads the research towards original artistic manifestations and concerns, which leads me to pay great attention to the aesthetic side in the context of the elaboration of compositional structures in personal artistic creation.

Keywords: arthropods, insects, entomology, specimen, watercolor, paper, graphic, papercutting.

Laura Duduleanu

Asistent universitar, Doctor în Arte Vizuale

Departmentul Grafică

Facultatea de Arte şi Design

Universitatea de Vest din Timişoara

Timişoara, Romania 
E-mail: dorina.duduleanu@e-uvt.ro

\title{
Artopode. Aprofundări estetice ale tematicii prin metode selective de reprezentare în creația personală
}

\begin{abstract}
Rezumat:
Articolul propune să analizeze, din perspectiva artistului vizual, tematica insectelor în arealul artelor vizuale, ca fundament al cercetării prezentând evolutiv anumite aspecte istorice, tehnice, artistice şi conceptuale. Studiul de față evidențiază reprezentările anumitor specimene în arealul creației artistice şi analizează trei etape ale actului creator - de la simpla curiozitate, la ştiinţă şi până la valoarea pur estetică - din acest demers făcând parte observațiile efectuate în domeniul entomologiei. Surprinderea fenomenului de decontextualizare a artropodelor din mediul natural, conduce cercetarea spre manifestări şi preocupări artistice inedite, fapt ce mă determină să acord mare atenție laturii estetice în contextul elaborării structurilor compoziţionale din creația artistică personală.
\end{abstract}

Cuvinte cheie: artropode, insecte, entomologie, specimene, acuarelă, hârtie, grafică, decupaj.

\section{Introduction}

Through this visionary strand, in order to understand how arthropods enter the iconographic area of fine arts, an investigation of visual representations will be pursued, reviewing an important part of art history, which will highlight to what extent artists have contributed to the foundation and establishment of the characteristics of what is defined as the natural world. The fundamental concept discussed resides in the contribution of the artistic vision, in the figuration of insects, as an evolutionary stage of their own creation, and seeks to specify the significance and intention of this thematic concern. This area includes a process that supports to some extent an aesthetic or dogmatic subjectivism, because the history of symbols confirms that any sign can be enveloped by an aspect of palpable or intangible symbolic value (Eliade, 2013). The study will be directed towards the moment when the theme of insects in artistic creation will generate new meanings and the modes of visual expression will embody increasingly fascinating configurations that will facilitate a profound contact between creator and viewer.

The bright carapaces and fragile joints of beetles, the iridescent bodies and reticulated wings of dragonflies, the limitless variety of patterns and colors on the wings of butterflies and moths are among the most interesting visual elements of the 
arthropod world. The insect empire represents a whole inspirational arsenal. A means of visual expression that implies the need for precision, perfectly in keeping with the artist's ability, curiosity and desire to make an impression. The visual image becomes the different way in which the natural world can be controlled, through which certain ephemeral characteristics are encapsulated, making it possible to exhibit one's own language, on an imaginary but naturalistic plane.

\section{Analytical figuration of insects}

Before the 16th century, insects were depicted in various ways, mainly in the ornamental register of ornated manuscripts, on the pages of which they often cast subtle shadows in the trompe l'oeil manner alongside other small objects, each of these elements having a precise symbolic meaning. Between the heyday of the Renaissance and the end of the Baroque era, artistic creation turned its attention to a new theme the study of insects and their life cycle - which merges perfectly with the fascination of the moment, namely, to own the curiosities of nature (Neri, 2011).

Certainly, the best-known study depicting an insect is Albrecht Dürer's 1505 painting The Stag Beetle, the German master's heyday. Conditional on directing attention to the individual specimen, this innovative manner of representation, referred to by Janice Neri as the 'logical specimen' (Findlen, 1994), would continue to influence the depiction of insects in the early modern period. With the introduction of this mimetic subject, the artist was faced with the challenge of expressing creative skills of great precision, which at the same time succeeded in demonstrating a refined artistic talent and the ability of great observation. On the same level, this type of interdisciplinary study highlights how the need to examine and represent nature interferes with humanity and the evolution of species.

With the passage of time, arthropods are seen as exotic rarities worthy of display, often ostentatiously flaunted both in cabinet room closets and introduced as study items in most works dealing with still life and in systematized natural science collections.

Despite the often-tiny size of the subjects and the hard-to-see chromaticism, the popularity of visual representations of insects in the 17 th century corresponded precisely to their growing importance in entomology. At the same time, there was an interest in the unknown, particularly in species from far-off lands, with aspects, which made it possible to make comparisons and analogies between subjects (Davis, 1997). At the same time, we can state that the cultural change from a static world view to a dynamic 
view, the endless transformation of natural sciences and historical perspective generates the seeds of a scientific view of reality.

It will therefore be noted that by far the most active phase of arthropod representations in the history of art was the 17th century, a period in which we find the richest moment of inspiration in the visual arts, a period in which works abound not only in number but also in variety of species (American Entomologist, 2013). Evolutionarily, the research is led towards the moment when the theme of insects in artistic creation will generate new meanings, and the ways of visual expression will embody more and more impressive forms, determining a direct relationship between creator and viewer.

Towards the end of the 19th century, a new art developed strongly, an art in which the enthusiasm for natural motifs - plants, flowers, insects - was predominant, thus Art Nouveau became an artistic movement with an incomparable visual aspect, abounding in detail, and the stylization of elements existing in nature, the main visual language through which this fascinating art manifested itself. In jewelry design, arthropods are a highly prized ornamental model, so that we see a variety of specimens in the creations of the most important masters who have been intensely active over several decades (Fahr-Becker, 2007). With the mid-20th century, remarkable stylistic breaks in the visual arts representations occur, so that arthropods become a subject of study that often reveals the artist's phobia towards certain specimens. The repetitive use of the same specimen brings to the fore the transposition with visual means of intense cognitive messages that aim to create a direct relationship between creator and viewer.

Thus, at the end of this argument, we can conclude by observing that the universal factor that governs all artistic creation, regardless of the period to which we turn our attention, is the perpetual inquisitive human spirit. Every artist, whatever his medium of representation, has demonstrated an attitude involving the phenomenon of decontextualizing the subject from the natural setting in order to use aspects that refer to the scientific, symbolic or aesthetic side of certain specimens.

\section{The beauty of the imaginary in personal artistic creation}

In terms of personal artistic creation, the theme of arthropods is the basis for the discussion of the present work, so that the manifestation of plastic creation, through its figurative and experimental research, is constantly looking for new configurations and forms of artistic expression. For the fact that the entire personal creation is dominated 
by using three working techniques: watercolor, papercutting and paper impression, the relationship created between the processes, is often oriented towards the fusion of elements of plastic language, so that the visual expression is constantly redefined in an attempt to highlight either the figurative characteristics of the arthropods or certain nonfigurative chromatic fusions (Fig. 1).

In what follows, I will attempt an eloquent translation into words of my own creation, so that this possible investigation, may highlight the main research in the area of artistic concerns of the entomological field. Each technique, including the more experimental ones, has extended the thematic sphere into a fascinating and surreal area.

Taken as an autonomous entity, the image represents an organization according to certain theoretical principles of forms, linked to previous feelings and experiences, where artistic creation becomes a reflection of the need to escape from immediate reality, a pendulation between the concrete and the illusory. The amount of distortion of recognizable reality is potentiated by inexhaustible meanings, ambiguity is often a phenomenon that arouses curiosity and fixes certain landmarks between the two environments palpable-real and illusory-imaginary. The inner universe seeks a means of externalizing feelings, thoughts and not least knowledge of the environment, and artistic creation is the only means of expression formed by a universal language.

With this kind of representation, one can notice a way of visual expression that involves the decontextualization of some elements of nature, which with this change are given, by extrapolation, the function of objects. This system of using elements taken from their natural environment has as its reference and inspiration the boundless vision found in the late Renaissance period, so this type of artistic manifestation can be defined as a relationship of observation of nature in order to organize frames with a new aesthetic function. The context is that of representing arthropods as a single whole - of living creatures forming a quiet kingdom - which can be studied and understood through descriptive-illustrative creations that offer the viewer a compositionally structured plastic language. (Fig. 2) Michel Foucault, in his book The Order of Things, states that "to observe is therefore to be content to see. To systematically see a few things. To see what, in the slightly confused richness of representation, can be analyzed, can be recognized by all and can thus be given a name that everyone will be able to understand..." (Foucault, 1996). Given this important attribution, we can only admire each figurative representation as a mirror of reality and a sincere way of conveying ideas through the image. 
On the whole, the language of watercolor becomes the technical process that allows me to present both certain chromatic concentrations and dilutions that create the impression of inner pulsation and precise, mimetic depictions of entomological or zoomorphic forms. In the spirit of communicating a sensitive compositional orientation, watercolors can bring out a lyrical incantation, which is often orchestrated in diaphanous, uncontrived shades, giving the work a playful atmosphere of a psychogram.

Thus, although throughout my artistic activity, watercolor is the technique most often used, I have also experimented with another method of obtaining paper-printing effects, and because I will refer to this process in what follows, I will call it the paperimpression technique. This needs to move out of the area of traditional processes, limited by conventionality, has evolved into a genre of variable configuration containing a wealth of tonal and chromatic fusions. The development and refinement of such a method over time highlights the fact that the ways of printing on paper are limitless, each result having varied expressive qualities, that can be compared to those acquired in watercolor or aquatint engraving.

During several years of technical trials and experiments - during which time I used a wide range of materials - I managed to achieve some spectacular chromatic impressions on the surface of the paper, which led me to start a new stage of exploitation of the plastic space. The process steps, involve an action of transferring rusted or corroded portions of the surface of a metal plate onto the moistened sheet of paper, and in order to create dilutions and tonal fusions, I used various liquids that serve to accelerate the value intensities (Fig. 3). Thus, the white of the moistened paper absorbs to some extent different densities of stains, coagulations that can vary depending on the metal surface, the quality of the paper, the amount and color of the liquid and especially the time interval. In this way, I gradually mastered much more easily the rendering of shapes, variable textures, areas of chromatic contrast, gradation of grey steps and free fields, which can be perceived as areas of respite (Fig. 4).

Depending on the insect studied, the particular aspects I noticed led me to express my admiration for such a wide variety of specimens. Close to the entomological spirit and the translucent specificity of watercolors, but seeking to confer a personal lyrical touch, I began a thematic and conceptual path, gradually seeking to consolidate itself more and more on the artistic level (Fig. 5). 
The foundation of the arthropod theme in the field of visual arts is the field of entomology, which has contributed to the foundation and establishment of the specific characteristics of each specimen, and the image of insects becomes a practice that complements the research carried out. We have seen in the evolution of art history that insects have been depicted in various poses, the motives being different depending on the period to which we turn our attention. In terms of personal creation, the aim of exploring this subject has various aspects. In other words, the present research has evolved out of a pure aesthetic interest as well as of the desire to expose new ways and configurations of representing subjects that often repulse us.

\section{Discussion}

In their structural development the chapters of the article highlight some important aspects for the present research through:

- Adopting some symbolic interpretations with a universal character, which attest the figuration of the arthropods in visual arts, where the order of interpretations seeks to highlight certain cultural areas and can reveal a different semantic potential according to the progress of socio-human sciences;

- The curiosity for the anatomical and aesthetic characteristics of the insects, surprising the phenomenon of de-contextualization of the arthropods from the natural environment and the special role that the scientific researches had in order to elaborate the specific illustrations in the entomological field;

- The case studies of various artistic periods that refer precisely to the interest shown for the inclusion of insects in a series of works representative for the present research, which reveals by language the foundation of the plan of personal artistic creation;

- The study of some artists and their representative works for the present research, from different artistic periods that have shown interest in the study of insects;

- Surprising the ideological and conceptual thematic area so it can render some aspects related to the improvement of the technical execution and the plastic language as a fundamental part of its own creation, so that the expressive visual offer correlates with the recognizable forms of the insects; 
- Highlighting and motivating the choice of such a subject in relation to personal artistic creation and its multiple valences in the search for the configuration of forms and the expressiveness of the compositional space.

Thus, although the research of the thematic area evolves in a strictly personal view, supported by three technical ways of working, the subject of arthropods highlighting certain hypostases related to the aesthetic peculiarity of each specimen, in the thematic content observing a particular interest for the balance created between the imaginary and real plan. The deepening and elaboration of these plurivalent directions of the creative act reveals a possible motivation for my affinity for the various arthropod artistic representations and comes to emphasize the symbolic character found in the iconographic area of the visual arts.

\section{Conclusion}

The essential notion discussed in the above lines is a mixture created between the contributions of artistic, entomological or amateur visions that feel attracted by the analytical representation of insects as a stage of their own creation and seek to specify the intention and meaning of this thematic manifestation. Against the backdrop of the different forms, anatomical volumes, materiality and chromatic richness, insects become an unusual subject that allows itself to be discovered as it is explored. This interest in certain particularities of entomology will generate a world dominated by corporeality in the imaginative realm, with frequent references to the affective plane. Thus, the attributes of the visible seek to form images within which various structures are revealed that refer to the natural environment. The oscillations created between figurative and non-figurative forms have a strong descriptive-illustrative feature that leads the viewer towards an imaginary space supported by sinuous spatial structures.

The present research was intended to be the product of artistic and research concerns structured from the general to the particular level, focusing on the field of entomology, present to a certain extent in the creation of artists throughout the history of visual arts. Aimed at highlighting the fundamental features that particularize the theme of arthropods, the study seeks to point out relevant particularities involving both historical connections and the definition of concepts of representation of artistic creation.

Therefore, although the research of the thematic area evolves in a strictly personal vision, supported by three technical ways of working, the arthropod thematic highlights 
certain hypostases related to the aesthetic particularity of each specimen, in the content there is a particular interest in the balance created between the imaginary and the real plane. The deepening and elaboration of these polyvalent directions of the creative act reveals a possible motivation of my affinity for the different researches of arthropod representation and emphasizes the symbolic character found in the iconographic area of visual arts.

At the projective level, thematic and technical artistic experiments prove to be experiences that facilitate compositional variations of the images and exalt a dynamic figurative area of the fusion process between scientific study and artistic creation.

In the elaboration and interpretation of the present research, the theme beyond all, captures the problem of the visible and at the same time of the visual, addressing certain theoretical and practical notions aimed at strengthening as much as possible a broad assessment of the subject, thus, the fundamental character of the arthropods, to travel a spectacular route in the magical world of visual arts.

\section{References:}

American Entomologist, 59, 1, 34. (2013). Spring.

Davis, N.Z. (1997). Women on The Margins: Three Seventeenth-Century Lives. Cambridge, Massachusetts: Harvard University Press, 56-154.

Eliade, M. (2013). Imagini şi simboluri. Bucureşti: Humanitas, 47.

Fahr-Becker, G. (2007). Art Nouveau. Bucureşti: NOI Distribuţie.

Findlen, P. (1994). Possessing nature: museums, collecting, and scientific culture in early modern Italy, University of California Press, London.

Foucault, M. (1996). Cuvintele şi lucrurile. Bucureşti: Univers, 177.

Neri, J. (2011). The Insect and The Image, Visualizing Nature in Early Modern Europe, 15001700. Minnesota: University of Minnesota Press, xii. 


\section{Appendix}
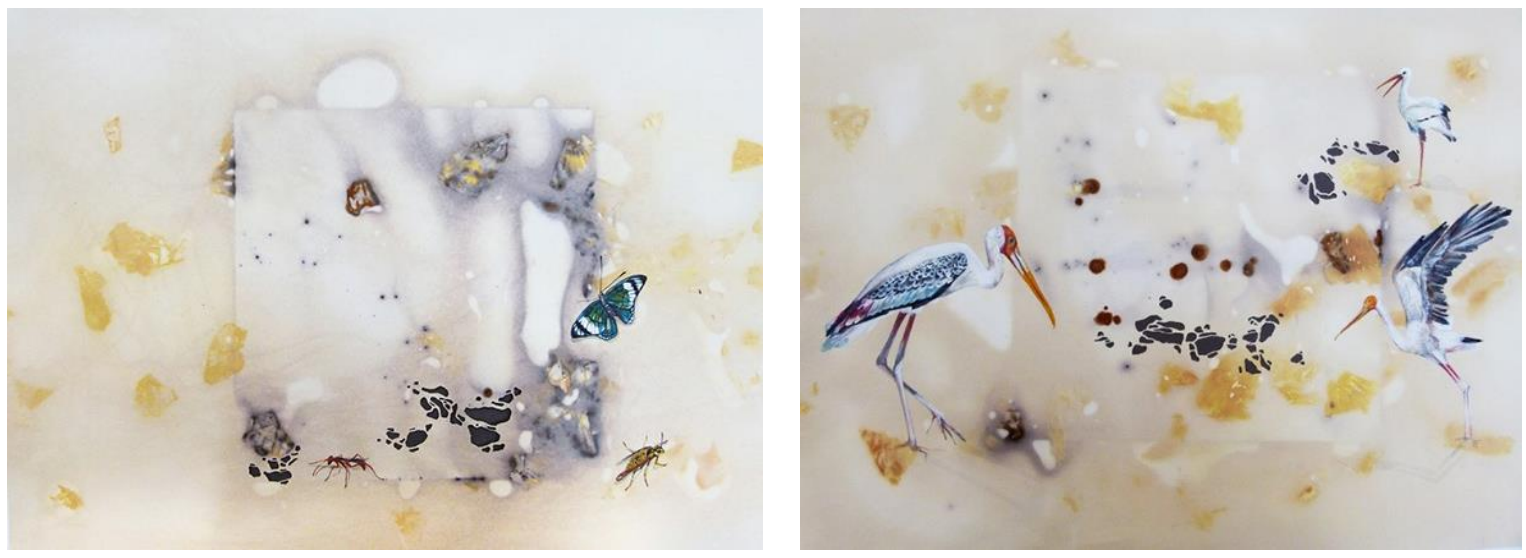

Figure 1. Laura Duduleanu, Illustration, watercolor, papercutting, paper impression. Private collection

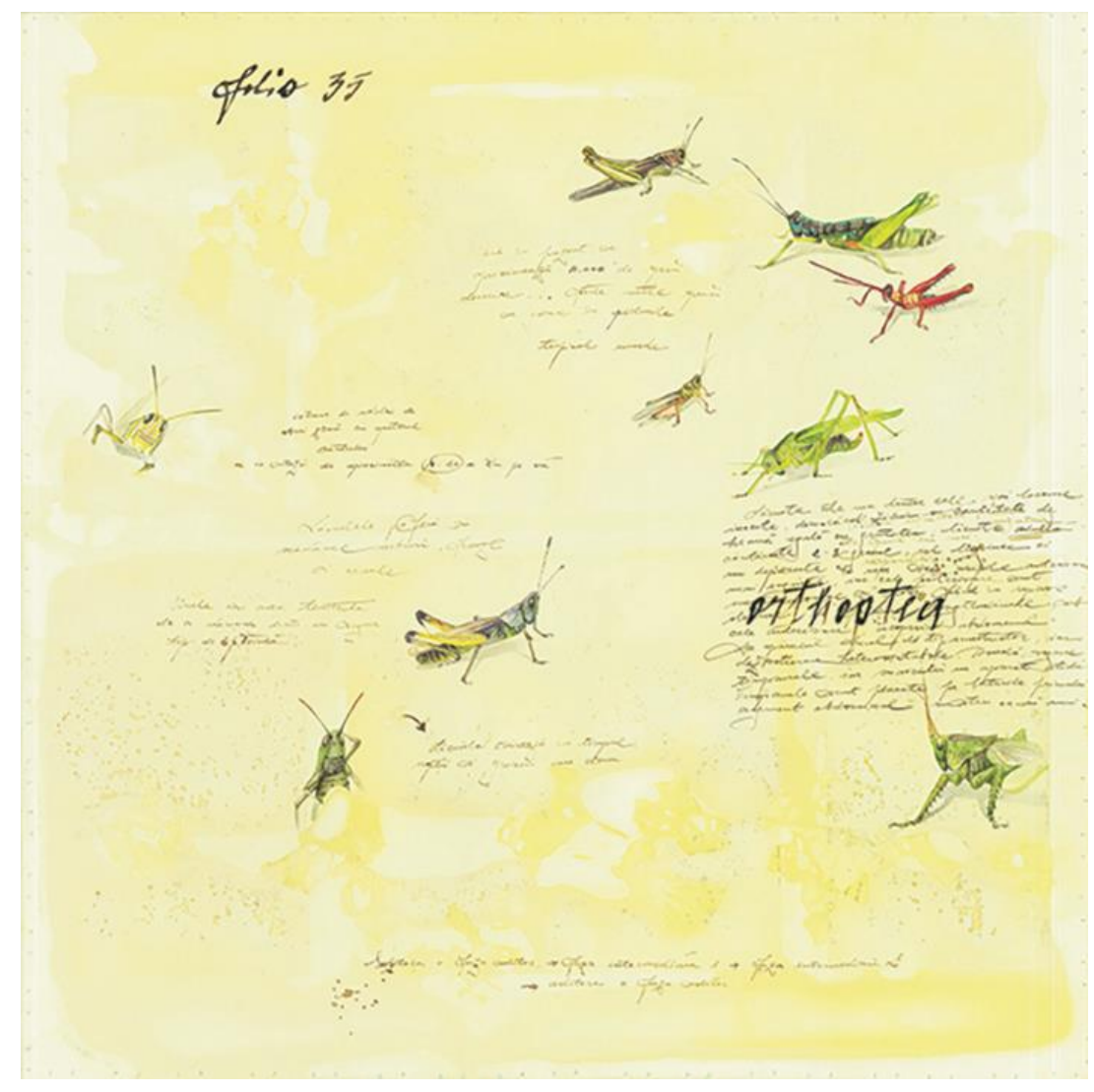

Figure 2. Laura Duduleanu, Arthropods - Orthoptea, folio 3, watercolor, paper impression, ink. Private collection 


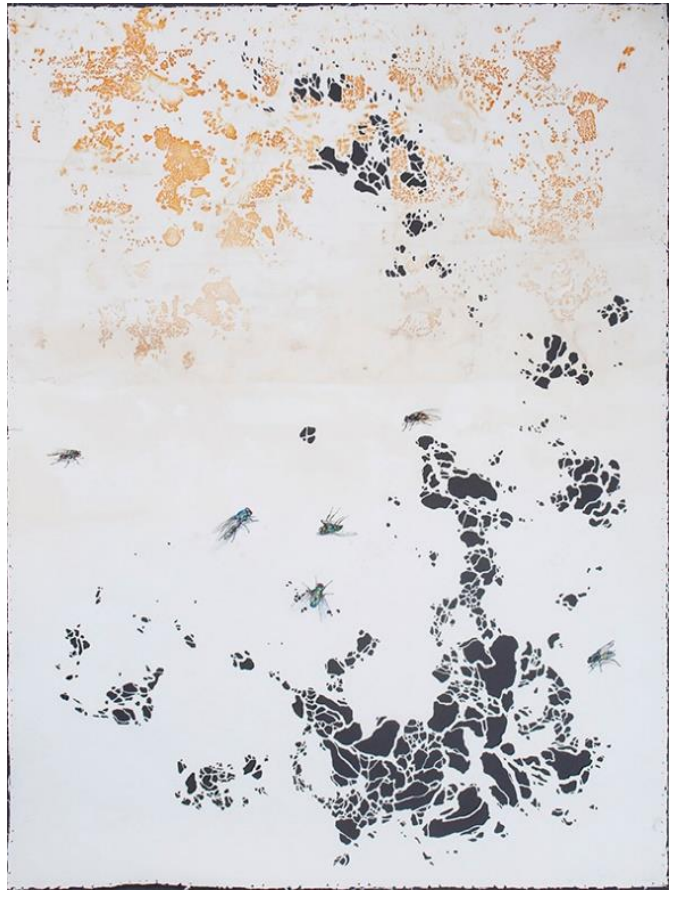

Figure 3. Laura Duduleanu, Fly-Away, papercutting, paper impression, watercolor. Personal collection

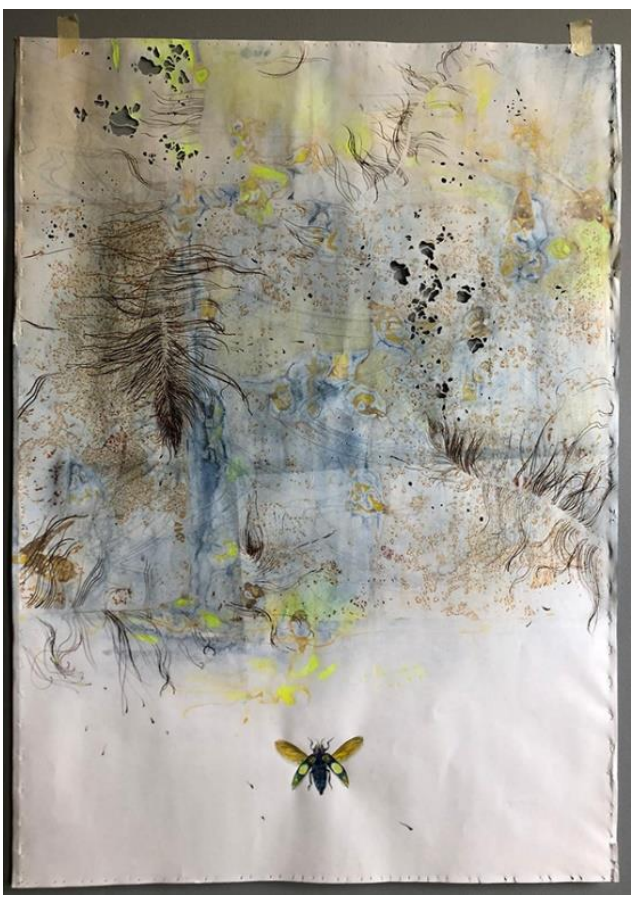

Figure 4. Laura Duduleanu, Chasing Memories, watercolor, papercutting, paper impression. Personal collection

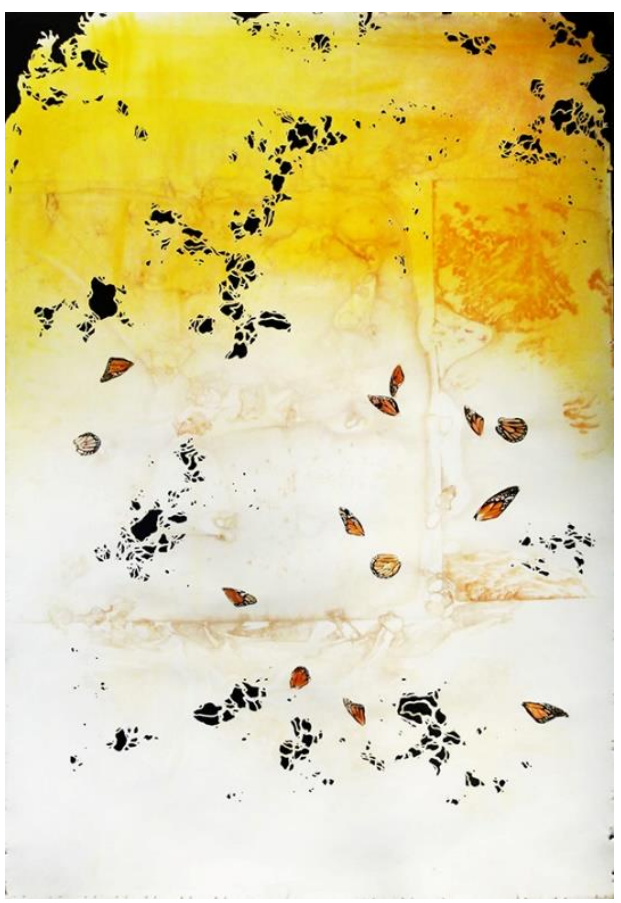

Figure 5. Laura Duduleanu, In the Aftermath of Love, watercolor, paper impression, papercutting. Private collection 